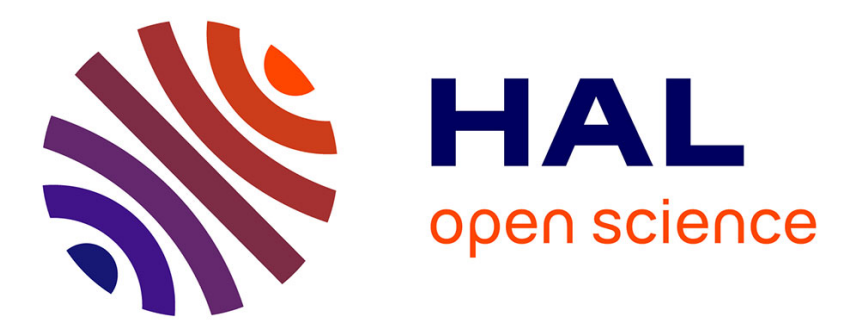

\title{
Data Processing for Assessment of Meteorological and Hydrological Drought
}

\author{
Nina Nikolova, Kalina Radeva
}

\section{To cite this version:}

Nina Nikolova, Kalina Radeva. Data Processing for Assessment of Meteorological and Hydrological Drought. 2nd International Conference on Information Technology in Disaster Risk Reduction (ITDRR), Oct 2017, Sofia, Bulgaria. pp.145-160, 10.1007/978-3-030-18293-9_13 . hal-02280318

\section{HAL Id: hal-02280318 \\ https://hal.inria.fr/hal-02280318}

Submitted on 6 Sep 2019

HAL is a multi-disciplinary open access archive for the deposit and dissemination of scientific research documents, whether they are published or not. The documents may come from teaching and research institutions in France or abroad, or from public or private research centers.
L'archive ouverte pluridisciplinaire HAL, est destinée au dépôt et à la diffusion de documents scientifiques de niveau recherche, publiés ou non, émanant des établissements d'enseignement et de recherche français ou étrangers, des laboratoires publics ou privés. 


\title{
Data Processing for Assessment of Meteorological and Hydrological Drought
}

\author{
Nina Nikolova ${ }^{1}$ and Kalina Radeva ${ }^{2}$ \\ ${ }^{1}$ Sofia University, Faculty of Geology and Geography, Sofia, Bulgaria \\ nina@gea.uni-sofia.bg \\ ${ }^{2}$ Sofia University, Faculty of Geology and Geography, Sofia, Bulgaria \\ kalinadeabv.bg
}

\begin{abstract}
Accurate and reliable data processing is of primary importance for drought assessment. It helps decision makers to lay out mitigation measures within the context of drought preparedness planning and water resources management. In order to understand meteorological and hydrological drought, we need to identify drought characteristics (duration, severity and spatial extent). Drought indices are essential tools quantifying drought severity and identifying its frequency and duration. For the calculation of drought indices, availability of long time series of undisturbed, good-quality observational data is essential. The studied area cover a Bulgarian part of the catchment of Struma River which is one of the largest Bulgarian rivers. The general aim of this research is to evaluate the occurrence of hydrological and meteorological droughts in Struma River basin and to show utilization of various indices for comparative analysis of meteorological and hydrological drought. Drought events are identified using the following indices - Standardized Precipitation Index (SPI), Standardized Precipitation Evapotranspiration Index (SPEI) and Streamflow Drought Index (SDI) for time scales 6 and 12 months. Additionally to these indices, we use also Rainfall Anomaly Index (RAI) and introduce Streamflow Anomaly Index (SAI). The main investigated period is $1962-2016$.
\end{abstract}

Keywords: Drought, Precipitation, River Runoff, SPI, SDI

\section{Introduction}

Drought is a major natural hazard with multiform impacts on the environment, the economy and society. Drought affects more regions and more people globally than many other natural hazards [1]. The American Meteorological Society have grouped various kind of drought into four categories: meteorological, agricultural, hydrological and socioeconomic droughts. The four categories are associated with different components of the hydrologic cycle. Generally, precipitation is the driving and critical factor in the hydrologic cycle. Meteorological drought is an extreme weather phenomenon having the character of an atmospheric anomaly caused by a period of below-normal rainfall. Disruption of the water balance of a given area due to a shortage of rainfall and strong evapotranspiration (meteorological drought) consequently causes excessive drying of 
the soil (soil drought), lowering the groundwater level and reducing water flows in the rivers (hydrological drought). Among the different types of droughts, the hydrological component is the most important, given the high dependence of many activities (industrial, urban water supply and hydropower generation), on the surface water resources [2]. Hydrological droughts also have a significant impact on water quality by disturbing the river's natural processes of self-purification. Hydrologically, the region impacted by drought is not only limited to the river network and its vicinity, but also to the whole basin [3]. Reasons for the occurrence of hydrological drought are complex, because they are dependent not only on the atmosphere, but also on the hydrological processes that feed moisture to the atmosphere and cause storage of water and runoff to streams [4]. According to Van-loon [5], hydrological drought has the most significant effects in almost all different sectors as shown in Table 1. Efficient early warning system against drought and integrated water resource management requires proper interpretation of area monitoring data at the drainage-basin scale. The success of drought preparedness planning and mitigation depends, in particular, on how accurate the droughts are defined and drought characteristics are quantified. Therefore it is important to investigate both - hydrological and meteorological droughts in the river basin.

Table 1. The major drought impacts for different drought categories

\begin{tabular}{llccc}
\hline $\begin{array}{l}\text { Impact } \\
\text { category }\end{array}$ & $\begin{array}{l}\text { Impact } \\
\text { sub-category }\end{array}$ & $\begin{array}{l}\text { Hydro- } \\
\text { logical } \\
\text { drought }\end{array}$ & $\begin{array}{l}\text { Meteoro- } \\
\text { logical } \\
\text { drought }\end{array}$ & $\begin{array}{l}\text { Agricultural/ } \\
\text { soil moisture } \\
\text { drought }\end{array}$ \\
\hline Agriculture & $\begin{array}{l}\text { Rain-fed } \\
\text { Irrigation }\end{array}$ & $\mathrm{x}$ & $\mathrm{x}$ & $\mathrm{x}$ \\
River basins/ecosys- & Terrestrial & $\mathrm{x}$ & $\mathrm{x}$ & \\
tems & Cooling & $\mathrm{x}$ & & \\
Energy and industry & Hydro-power & $\mathrm{x}$ & & \\
Navigation & & $\mathrm{x}$ & & \\
Drinking water & & $\mathrm{x}$ & & \\
Recreation & & $\mathrm{x}$ & & \\
\hline
\end{tabular}

Source: Van-loon (2015)

The number of droughts will increase on a global basis due to global warming which leads to higher temperatures and favors dry conditions $[6,7]$. In the European Union (EU), more than 4800 drought-related impacts entries have been identified in the European Drought Impact Report Inventory (EDII) across 15 different impact categories from agriculture to water quality [8] and financial losses over the last 3 decades were estimated to over EUR 100 billion [9]. Climate change studies project longer, more frequent and severe meteorological droughts in southern Europe, especially in the Mediterranean and the Balkans including Bulgaria [10]. Both, geographic location and climatic conditions are favorable to the occurrence of droughts in Bulgaria. The country has experienced several drought episodes during the 20th century, most notably in the 
1940s and 1980s. Drought in Bulgaria was most severe in 1945 and especially in the year 2000 , with precipitation $30 \%$ less than the current climatic values [11]. Studies revealed that there is a general tendency towards drying during the last two decades in some parts of Bulgaria [12].

To counteract the negative effects of drought and to take appropriate action and preventive measures, reliable and proven indicators of the intensity of drought should be available. Drought indices are very important tools to monitor and to assess drought [13]. Although a multitude of drought indices exist, we select a subset of three indices to evaluate different types of drought: the Standardized Precipitation Index (SPI) [14], the Standardized Precipitation-Evapotranspiration Index (SPEI) [15, 16]; [17], the Streamflow Drought Index (SDI). A significant part of the drought indicators, described in the literature and used in the monitoring of drought in various regions of the world, is based on the amount of atmospheric precipitation. These include the Standardized Precipitation Index (SPI), recommended for use in the practical monitoring of drought $[14,18,19,20]$. SPI is used to detect periods of drought and assess its severity. It is used in the USA (for operational monitoring of drought by the National Center for Drought Prevention), and in Europe, among others in Germany [21], Greece [22], Portugal [23], Poland [24] and Bulgaria [25, 26, 27]. Another index recommended by WMO is the Standardized Precipitation-Evapotranspiration Index (SPEI). The original SPEI input parameters are precipitation and temperature data. Mathematically, it is similar to SPI, but it includes the effect of temperature variability. The SDI index has not been used and studied in Bulgaria, but it was applied to the analysis of regional droughts in Europe [28, 29], Asia [30, 31, 32], Turkey [33] and USA [34].

The main purpose of this study is to determine the frequency of occurrence of meteorological and hydrological drought in different periods over many years (19622016), based on the Standardized precipitation index (SPI), Streamflow drought index (SDI) and additionally Standardized precipitation evapotranspiration index (SPEI) and comparison of these indicators as criteria for assessing drought.

\section{Study Area and Data}

The trans-boundary Struma River basin has a total area of $16747 \mathrm{~km}^{2}$ and is the second largest catchment area in Bulgaria and the fifth longest Bulgarian river. Its basin is shared by four countries: Bulgaria $\left(50.6 \%, 8,473 \mathrm{~km}^{2}\right)$, Greece $\left(35.8 \%, 5,990 \mathrm{~km}^{2}\right)$, FYROM $(9.8 \%, 1641 \mathrm{~km} 2)$ and Serbia $\left(3.8 \%, 643 \mathrm{~km}^{2}\right)$. The total length of the river is about $390 \mathrm{~km}$. It springs from the Southern slopes of the Vitosha Mountain, in Bulgaria, (2180 m a.m.s.1.) and ends up in Aegean Sea (Strymonikos Gulf). After a southsoutheast route of $290 \mathrm{~km}$, Struma River leaves the Bulgarian territory near the Kulata village ( $85 \mathrm{~m}$ a.m.s.1.). The basin has a pronounced mountainous character sculpted by the hydrographic network and glacial denudation, with an average elevation of about $900 \mathrm{~m}$ above sea level. The climate in the Upper Struma River is moderate continental, while in the middle part - transitional continental with significant Mediterranean influence. Mean annual precipitation in the basin is $566 \mathrm{~mm}$ and potential evapotranspiration is $629 \mathrm{~mm}$. Most precipitation is concentrated in the winter months, with peak rainfall 
occurring from November through March and the summer is quite a dry season [27]. Annual precipitation values have ranged from $480 \mathrm{~mm}$ (in lower and southernmost parts, station Sandanski) to $\mathrm{mm}$ to $700 \mathrm{~mm}$ at the altitude higher than $1100 \mathrm{~m}$ (station Rila monastery).

The mean annual flow of the Struma River is $2242 \times 10^{6} \mathrm{~m}^{3}$, which constitutes $13 \%$ of the country's total precipitation and runoff with the coefficient of variation $\mathrm{Cv}$ $=0.32$ and $\mathrm{Cs}=0.57$. The internal variability of river runoff depends on combinations and distribution of rainfall, snow cover and air temperature. In the high mountain parts of the area, the river flow in the winter is low, with a minimum in February, as a result of the reduced water flow under the thick snow cover and low temperatures. In this part, heavy rainfall in the spring and the presence of intense snowmelt led to high water period with a peak in May (up to about $30 \%$ of the annual runoff). With the decrease of the altitude of the basins high water period shifts to the winter months, the maximum in the southernmost parts of the basin is in February. The low water period begins in July and continues until winter, with monthly minimum in September.

The Bulgarian part of the River Basin is home to 485000 people (7 \% of Bulgaria's total population). The main water users of surface water are domestic supply, livestock farming, industry, energy production and to a less degree irrigation [35]. The runoff variability is analysed on the bases of monthly data from nine stream gauging stations (see Table 2).

Table 2. List of stream gauging stations used in the research

\begin{tabular}{|c|c|c|c|c|c|}
\hline River & $\begin{array}{l}\text { Stream } \\
\text { gauging } \\
\text { station }\end{array}$ & $\begin{array}{c}\text { Drainage } \\
\text { area } \\
\left(\mathbf{k m}^{2}\right)\end{array}$ & $\begin{array}{l}\text { Average eleva- } \\
\text { tion of drain- } \\
\text { age area }(\mathrm{m})\end{array}$ & $\begin{array}{c}\text { Meteorological } \\
\text { station }\end{array}$ & $\begin{array}{c}\text { Altitude } \\
\text { (m) }\end{array}$ \\
\hline Struma & Pernik & 284.0 & 1018 & Pernik & 768 \\
\hline Struma & Boboshevo & 4320 & 974 & & \\
\hline $\begin{array}{l}\text { Sovolianska } \\
\text { Bistrica }\end{array}$ & Garlyano & 41.90 & 1682 & Kyustendil & 520 \\
\hline Eleshnica & Vaksevo & 315.3 & 1058 & & \\
\hline Rilska & Pastra & 222.0 & 1918 & Rila monastery & 1150 \\
\hline $\begin{array}{l}\text { Bistritsa } \\
\text { (Blagoevgrad) }\end{array}$ & Slavovo & 105.0 & - & Rila & 505 \\
\hline $\begin{array}{l}\text { Biistritsa } \\
\text { (Blagoevgrad) }\end{array}$ & $\begin{array}{l}\text { Blagoevgra } \\
\text { d }\end{array}$ & 206.5 & 1467 & Blagoevgrad & 424 \\
\hline Sushitska & Polena & 32.10 & - & & \\
\hline $\begin{array}{l}\text { Sandanska } \\
\text { Bistrica }\end{array}$ & Lilyanovo & 118.4 & - & Sandanski & 206 \\
\hline
\end{tabular}

The information about the precipitation is from six meteorological stations situated close to the stream gauging stations in an area with different geographical and climatic conditions (see Table 2). The main investigated period is $1962-2016$. The studied area 
with the geographical position of stream gaging and meteorological stations is represented on Figure 1.

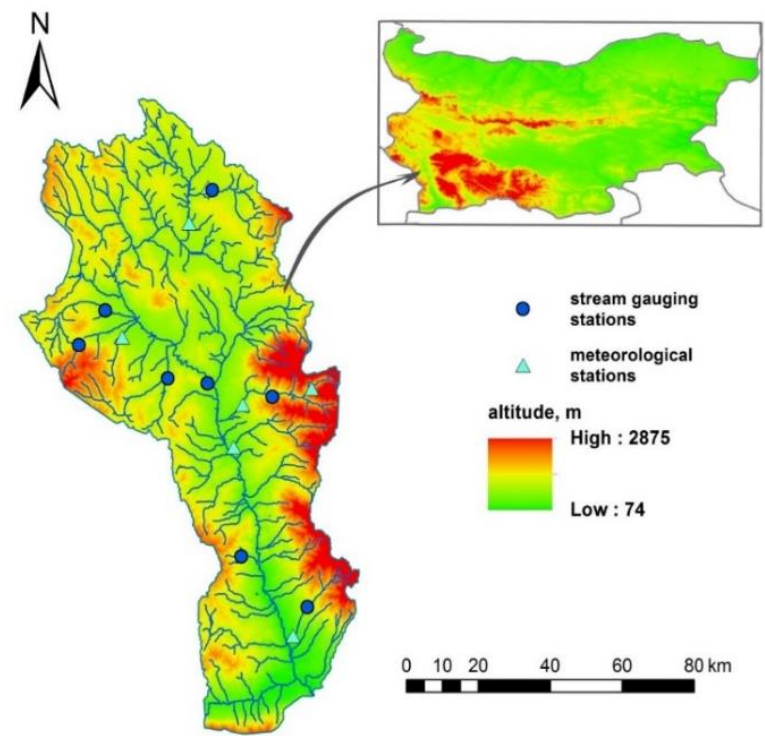

Fig. 1. Studied area and location of stream gauging and meteorological stations

\section{Methods}

The drought indices are important tools for clarifying the severity of drought events. They are mainly represented in a form of time series and are used in drought modeling and forecasting [4]. SPI was developed in Colorado by McKee et al. [14] to serve as a "versatile tool in drought monitoring and analysis". It is standardized and can be computed at different time scales, allowing it to monitor the different kinds of drought [36]. The SPI calculation for any location is based on the long-term precipitation data for a chosen period. This long-term record is fitted to a probability distribution, which is then transformed into a normal distribution so that the mean SPI for the location and desired period is zero [37]. The software provided by the National Drought Mitigation Center, University of Nebraska (https://drought.unl.edu/droughtmonitoring/SPI/SPIProgram.aspx, accessed by 10 February, 2019), is used for calculation of SPI.

Standardized Precipitation Evapotranspiration Index (SPEI.) is a relatively new drought index. The study of drought by SPEI in Bulgaria is still not well developed. SPEI uses the basis of SPI but includes a temperature component, allowing the index to account for the effect of temperature on drought development through a basic water balance calculation [15]. The multi-scalar character of the SPEI enables its use in vari- 
ous scientific disciplines to detect, monitor and analyze droughts [15]. SPEI can measure drought severity according to its intensity and duration and can identify the beginning and the end of drought periods. It can be calculated for time steps of as little as 1 month up to 48 months or more. Monthly updates allow practical application, and the reliability of the results increases with the increasing of the available time-series data.

Streamflow Drought Index (SDI) is a very simple and effective index for hydrological droughts [28]. The SDI for each gauged station was determined using the following relation:

$$
V_{i, k}=\sum_{j=1}^{3 k} Q_{i, j} i=1,2 \ldots j=1,2 \ldots, 12 k \quad(1)=1,2,3,4
$$

in which $\mathrm{V}_{\mathrm{i}, \mathrm{k}}$ is the cumulative streamflow volume for the $\mathrm{i}$-th hydrological year and the $\mathrm{k}$-th reference period, $\mathrm{k}=1$ for November-January, $\mathrm{k}=2$ for November-April, $\mathrm{k}=$ 3 for November-July, and $k=4$ for November-October. Based on the cumulative streamflow volumes " $\mathrm{V}_{\mathrm{i}, \mathrm{k}}$ ", the Streamflow Drought Index (SDI) is defined for each reference period $\mathrm{k}$ of the $\mathrm{i}$-th hydrological year as follows:

$$
S D I_{i, k}=\frac{V_{i, k}-V_{k}}{S_{k}} i=1,2 \ldots, k=1,2,3,4
$$

where " $\mathrm{V}_{\mathrm{k}}$ " and " $\mathrm{S}_{\mathrm{k}}$ " are respectively the mean and the standard deviation of cumulative streamflow volumes of the reference period " $k$ " as these are estimated over a long period of time. In this definition the truncation level is set to "Vk" although other values based on rational criteria could be also used. Nalbantis and Tsakiris [28] quantify 4 states (classes) of hydrological drought for SDI, which are determined in an identical way to those used in the meteorological drought indices SPI and SPEI. States of drought are defined by an integer number using criteria as per Table 3.

Table 3. Classification of drought conditions according to the SDI, SPEI and SPI

\begin{tabular}{ccc}
\hline State & Description & Criterion \\
\hline 1 & Extremely Wet & VDI;SPI;SPEI $\geq 2.0$ \\
2 & Very Wet & $1.5 \leq$ SDI;SP;SPEI I $\leq 1.99$ \\
3 & Noderately Wet & $1.0 \leq$ SDI;SPI;SPEI $\leq 1.49$ \\
0 & Non-drought & SDI;SPI;SPEI $\geq 0$ \\
-1 & Mild drought & $-1.0 \leq$ SDI;SPI;SPEI $\leq 0.0$ \\
-2 & Moderate drought & $-1.5 \leq$ SDI;SPI;SPEI $\leq-1.0$ \\
-3 & Severe drought & $-2.0 \leq$ SDI;SPI;SPEI $\leq-1.5$ \\
-4 & Extreme drought & SDI;SPI;SPEI $\leq-2.0$ \\
\hline
\end{tabular}

In the proposed methodology, the reference periods start from November of each year, which is considered the beginning of hydrological year in Bulgaria. The drought 
assessment is made using two overlapping periods: at annual level - hydrological year (November - September) and at seasonal level - cold half-year (November - April). In order to evaluate the drought during these two periods SPI, SPEI and SDI are calculated with a 12 and 6 month step, respectively.

The present paper aims to show the utilization of various indices for drought detection and analysis. Additionally to the above mentioned indices, we calculate also Rainfall Anomaly Index (RAI) which can be used for assigning the magnitudes to positive and negative precipitation anomalies. For analysis of negative anomalies and drought events the index is calculated by

$$
R A I=-3 \frac{P_{i}-\bar{P}}{\overline{E-\bar{E}}}
$$

where $P_{i}$ is precipitation for every year, $\mathrm{P}$ - average e precipitation for the investigated period, and $\mathrm{E}$ is average of ten lowest annual precipitation totals (driest years) for the investigated period.

RAI is used as a tool for meteorological drought investigation by Olukayode Oladipo [38], Keyantash and Dracup [36], Nikolova and Vassilev [39], Hänsel and Matschullat [40], Hänsel et al.[41], Fluixá-Sanmartín et al. [42] etc.

The same method was applied to annual streamflow data and Streamflow Anomaly Index (SAI) was calculated. The classification of dry periods according to RAI and SAI is shown in Table 4.

Table 4. Classification of droughts according to Rainfall Anomaly Index and Streamflow Anomaly Index

\begin{tabular}{cc}
\hline RAI / SAI & Classification \\
\hline-0.49 to 0.49 & Near normal \\
-0.99 to -0.50 & Slightly dry \\
-1.99 to -1.00 & Moderately dry \\
-2.99 to -2.00 & Very dry \\
$\leq-3.00$ & Extremely dry \\
\hline
\end{tabular}

\section{Results}

The SPI, SPEI and SDI values based on the meteorological and hydrological data from the Struma River Basin were calculated for the 6 and 12 month time scales during 19622016. We investigate hydrological year from November to October. Due to the climatic conditions in South Bulgaria, where a minimal rain period lasts from June to October, the SPI and SDI values of 6 months and above time scale step seem more useful than the 3 months one. The first period (November through April) includes the high-flow period of the rivers in the investigated area. The distributions of drought indices (SPI, SPEI and SDI) for the period November-April are provided in Figures 2. 

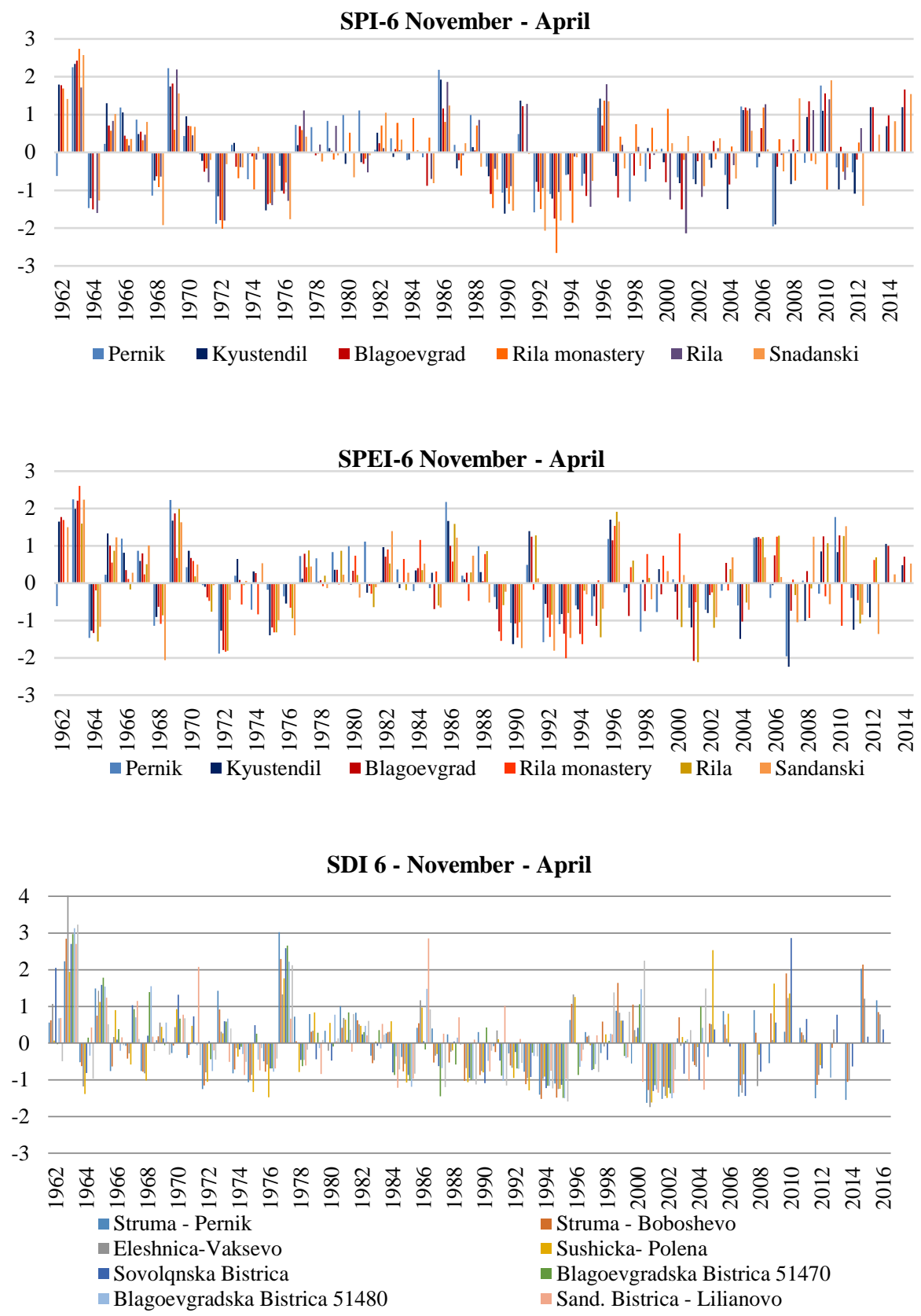

Fig. 2. Chronological distribution of drought indices for the period November - April 
The SPI distributions demonstrate that some stations exceed the threshold of classes for extreme drought (SPI <-2) during the years 1993 and 2001, when SDI indicates moderate drought (SDI $<-1,5)$. There is a good synchronicity between the SPI and SPEI. Small differences have been detected in separate cases in relation to drought severity only. However SPEI confirms the occurrence of meteorological drought established by SPI. The indexes showed that there was a significant drought problem during the years 1989-1996 and 2000-2002, in the middle and the south part of the basin.

According to SDI-6 for November - April, hydrological drought is observed in about 50 to $60 \%$ of the years in the investigated period. On the other side, the precipitation data and SPI- 6 shows, that meteorological drought for the winter-time is manifested in about 40 to $50 \%$ of the investigated years, but the severity is often higher than for the hydrological drought.

The distribution between mild, moderate, severe and extreme drought events at the different stations for the winter-time (November - April) for all the years is presented on Figure 3. Mild drought was the dominant drought state in all of the stations. Further results based on SDI do not show any extreme drought events as compared to the SPI index which shows extreme drought occurrences $(\mathrm{SPI} \leq-2.0)$ in three stations (Rila monastery, Rila, Sandanski) located in mountainous and south part of the basin.
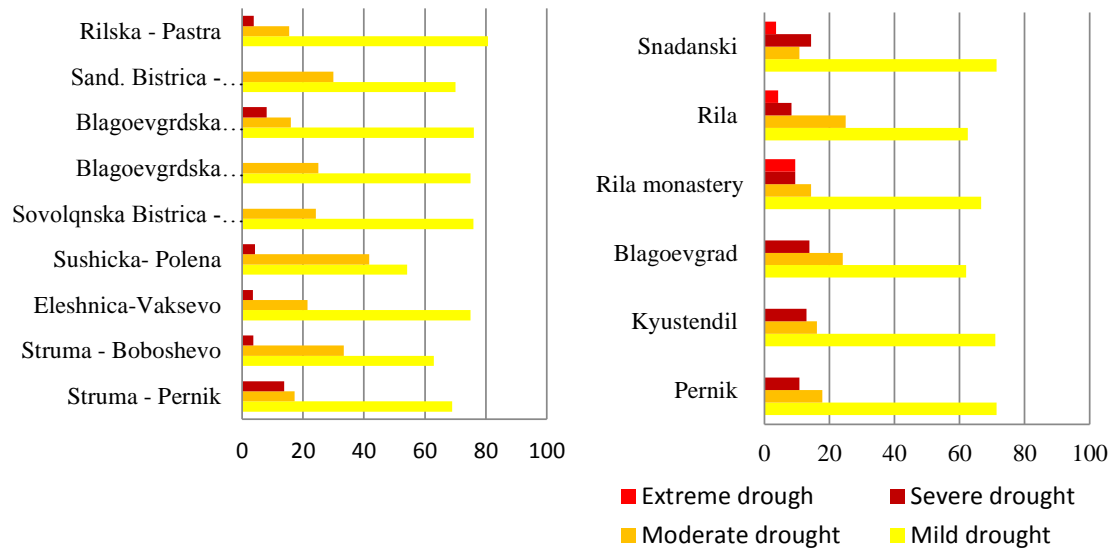

Fig. 3. Comparison of percentage of drought severity categories - 6 - month time step (November- April) of (a) SPI (b) SDI

In the second step, the analysis of the indices SPI, SPEI and SDI 12 months' time scale has been executed in order to evaluate the long-term drought episodes. The most widespread extreme 12-month drought occurs, according to SPI, in 1993. SPEI also shows drought occurrence in 1993, but the severity of the drought is lower than the one detected by SPI. On the other side, SPEI detects severe and extreme drought in 2000 and 2001 while SPI shows mainly, moderate drought (see Fig. 4). 


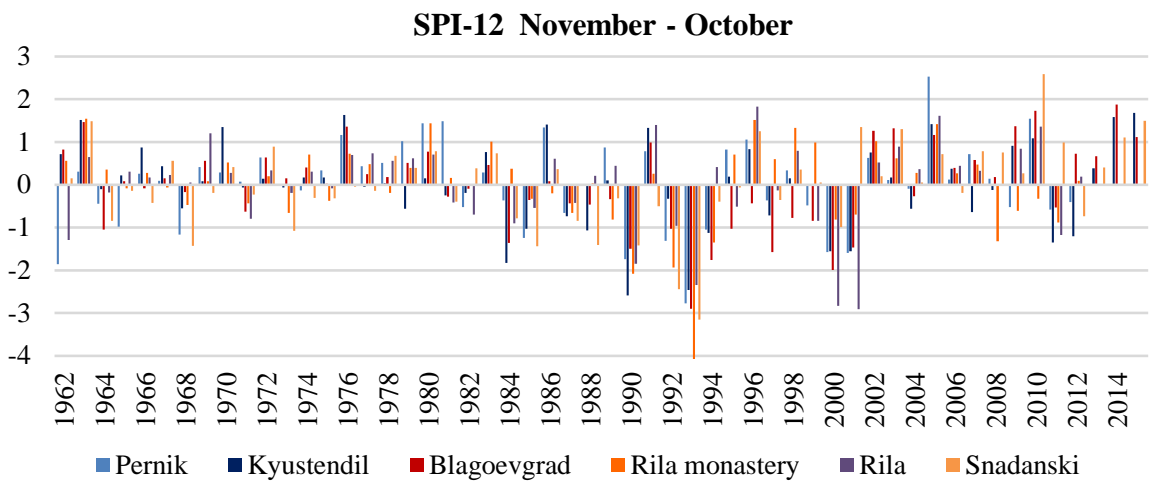

SPEI-12 November - October

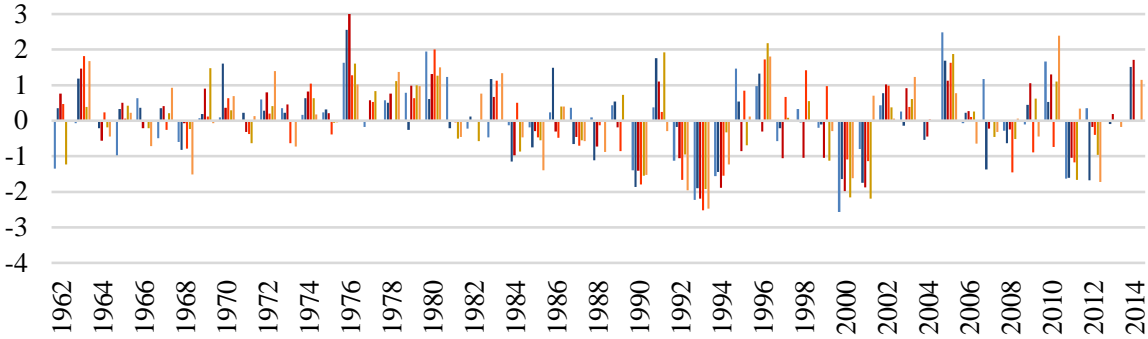

$\square$ Pernik $\square$ Kyustendil $\square$ Blagoevgrad $\square$ Rila monastery $\square$ Rila $\llbracket$ Sandanski

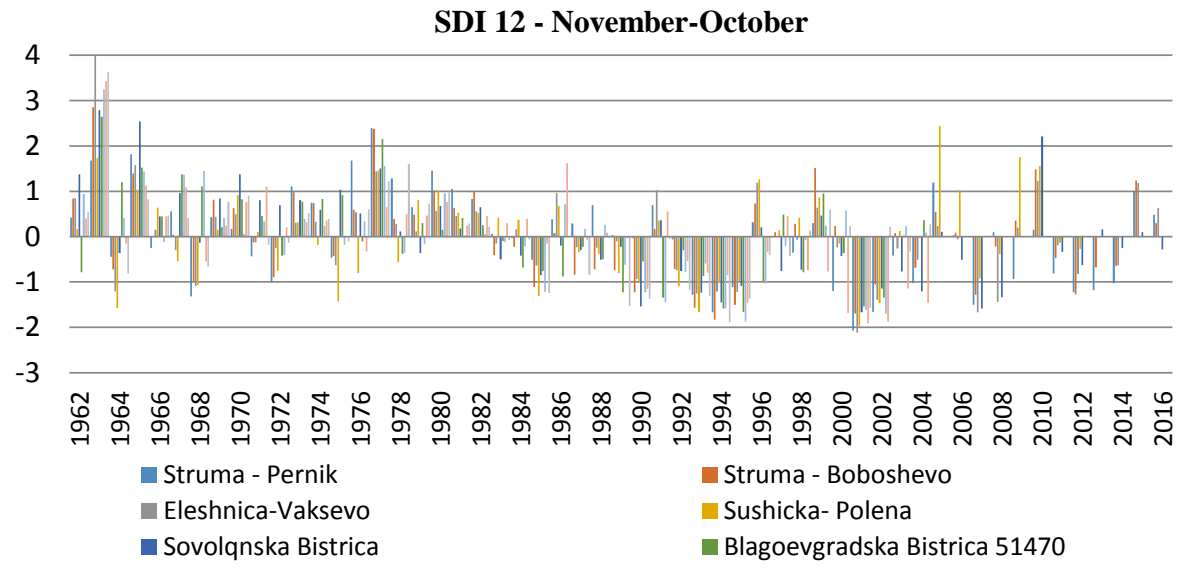

Fig. 4. Chronological distribution of drought indices for hydrological year (November - October) 
Sequences of dry periods (SPI, SPEI and SDI <-1,5) took place in 1983-1985, 19921995, 2000-2002, and for SDI, also in 2011-2014 (see Fig. 4). The severest meteorological drought among all the stations was detected in mountainous part of the basin i.e. Rila monastery and Rila stations. The year 1993 was identified as the driest year in terms of drought severity, as extremely dry (SPI value - 4.12). The years $2000(-2.83)$ and 2001 (-2.91) also were characterized as Extremely Dry. The longest hydrological droughts occurred in the periods 1992-1995 with a peak intensity of -1.83 (severe drought), and a mean intensity of -1.17 , and in 2000-2002 with peak intensity -2.114 (extreme drought) and a mean intensity of -1.13 .

Mild drought was the dominant drought intensity in all the stations (see Table 5.). An average of $65.68 \%$ for SPI and 64\% for SDI of mild drought occurred in the investigated area. Moderate drought intensities occurred at an average of $17.1 \%$ for SPI and $23 \%$ for SDI. Severe drought occurred at an average of $8.8 \%$ for SPI and $13 \%$ for SDI, respectively. According to SPI results extreme drought intensity is $8.2 \%$. There are only two cases of extreme drought in Struma River basin within this period according to SDI.

Table 5. Number of years and percentage (\%) occurrence of various degrees of drought in each of the stations according to SDI 12

\begin{tabular}{lcccc}
\hline \multicolumn{1}{c}{ Stations } & \multicolumn{2}{c}{ States of drought } & \\
& Mild & Moderate & Severe & Extreme \\
\hline Struma - Pernik & $13(50)$ & $10(38.46)$ & $2(7.69)$ & $1(3.85)$ \\
Struma - Boboshevo & $16(64)$ & $5(20)$ & $4(16)$ & 0 \\
Eleshnica-Vaksevo & $20(69)$ & $7(24.1)$ & $1(3.45)$ & $1(3.45)$ \\
Sushicka- Polena & $15(60)$ & $7(28)$ & $3(12)$ & 0 \\
Sovolqnska Bistrica & $20(69)$ & $6(20.7)$ & $3(10.3)$ & 0 \\
Blagoevgradska & & & & 0 \\
Bistrica 51470 & $16(72.7)$ & $3(13.65)$ & $3(13.65)$ & 0 \\
Blagoevgradska & $12(60)$ & $4(20)$ & $4(20)$ & 0 \\
Bistrica 51480 & $13(65)$ & $4(20)$ & $3(15)$ & 0 \\
Sand. Bistrica - & $14(63.6)$ & $5(22.8)$ & $3(13.6)$ & 0 \\
Lilianovo & & & \\
Rilska - Pastra & & & & 0 \\
\hline
\end{tabular}

Both indices SPI and SPEI show that at annual scale the drought is widespread in 1993 and 2000, when the drought is observed in all of the investigated stations, and in 2011 (the drought is observed in about $80-85 \%$ of investigated stations).

SPI and SPEI as well as SDI show great difference for the years 1984 and 1990. According SPI the year 1984 was dry in about $60 \%$ of investigated stations. On the other hand, the SPEI shows drought only in $20 \%$ of the stations. This can be explained by comparatively low values of air temperatures in 1984. Due to high temperatures in 1990, SPEI shows dry condition in all of the investigated stations and this was not the case when only precipitation (SPI) was considered.

Annual values of Rainfall Anomaly Index and Streamflow Anomaly Index are in coincidence with the results from the drought analysis by SPI and SDI. According to 
RAI and SAI the driest year is 1993, when extreme drought was observed (see Figure 5.). Both indices show also very dry period 2000-2001 and moderately dry 1983-1984.

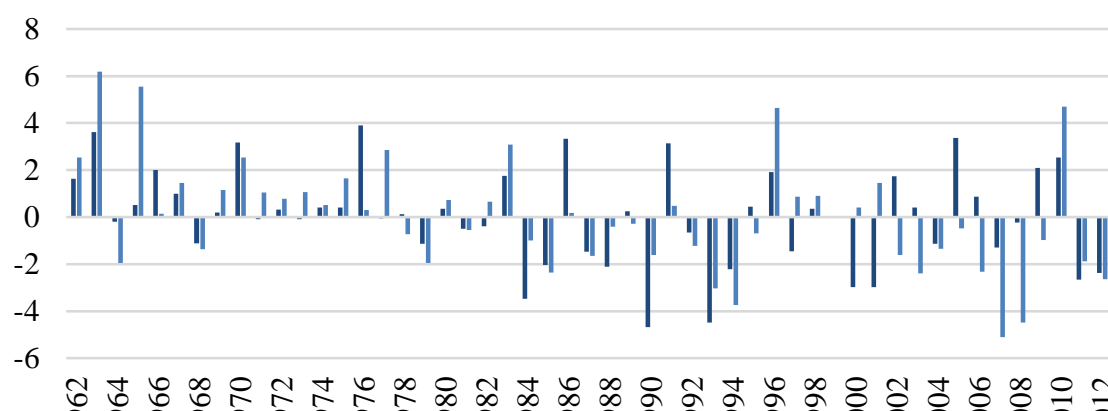

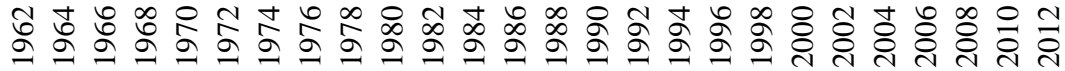

$\square$ RAI - Kyustendil $\square$ SAI - Sov. Bistritsa, Goranovo
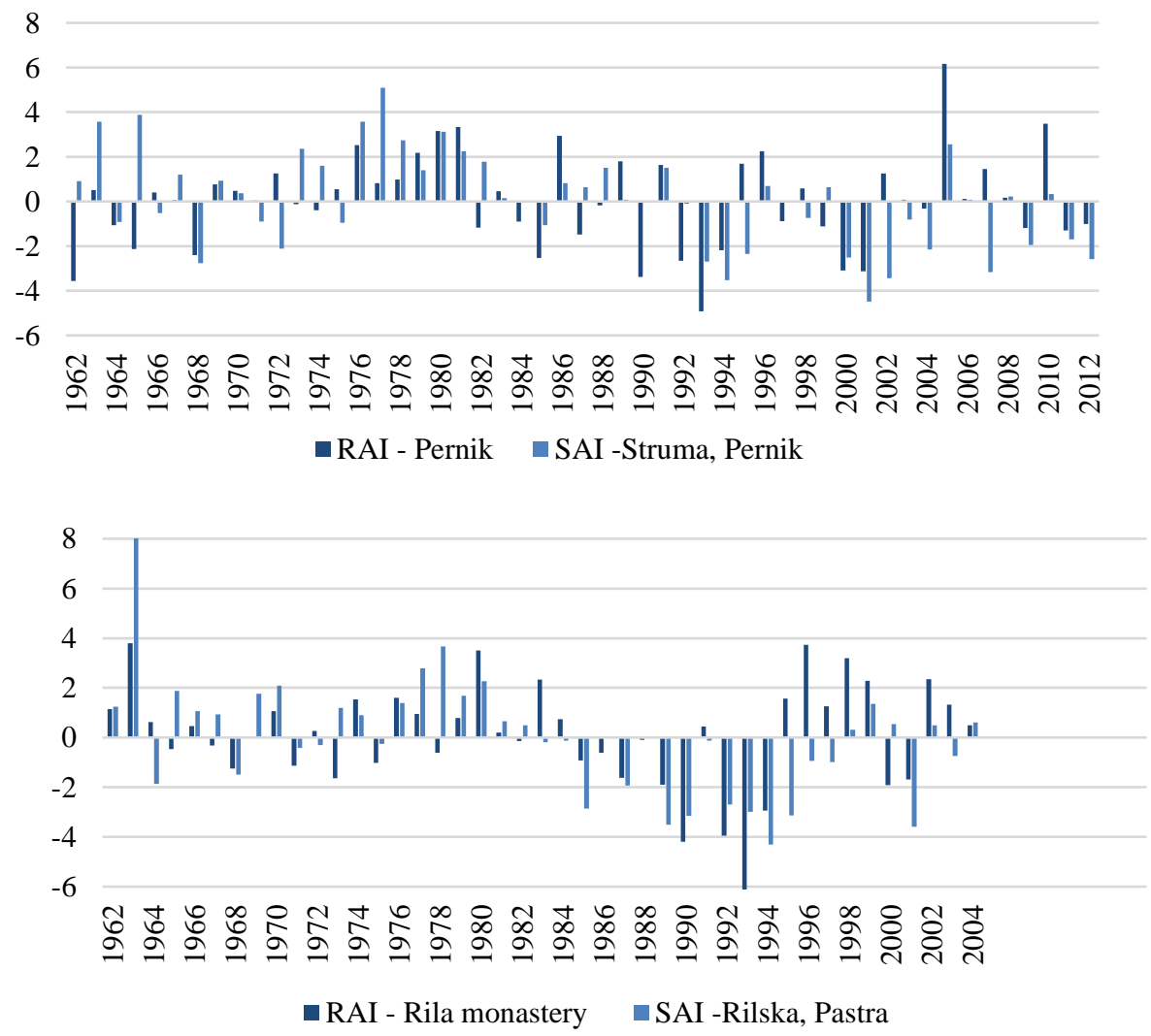

Fig. 5. RAI and SAI for selected stations 
The good synchronicity between RAI and SAI, as well as the results of SPI and SDI, allow us to conclude that SAI could be used for hydrological drought investigation. The advantage of RAI and SAI is the simplicity of the calculation and the fact that they are based only on the data for precipitation or streamflow respectively. According to Olukayode Oladipo [38] there is a negligible difference between RAI and the more complicated Palmer drought index. Hänsel et al. [41] suggest modification in the calculation of RAI and the use median instead of average and find high correlation with SPI. The utilization of RAI for drought analysis is pointed out by Fluixá-Sanmartín [42] who compare various indices as SPI, RAI, and percent of normal (PN)

\section{Conclusion}

Drought assessment indicators allow for easy interpretation of results and comparison of regions with different climatic conditions. The SPI and RAI are preferred for drought investigation due to easy provision with source data (precipitation only) and simplicity of the calculations. The same advantages have SDI and SAI for hydrological drought analysis. On other side, the indicators based only on climatic factors do not fully account for the drought development process. The use of only one element in the form of precipitation as input data (SPI) reflects in principle only one phase - atmospheric drought. The introduction of a second factor, as air temperature (SPIE), gives a more complete picture of the meteorological and humidity conditions of the area. The drought assessment using indicators based on flow data is a summary of the development of the drought process. According to the results most of the investigated area is drought-prone and it should be a priority of regional water management projects focusing on drought mitigation.

The SPI extreme drought category on the 12-month time scale occurs most frequently in the middle part of the basin. Similarly, results based on hydrological drought analysis shows that the severest drought events occurred in the upper and middle part of the basin during 1994 - 1993, 2000-2001 and 2007-2008. In most of the investigated areas the cases of mild and moderate drought increased, particularly over the last two decades (1990-2010).

The SDI analysis results in this work show that significant drought characteristics can be found in analysis periods of six months (November to April) and twelve months (November to October). The results based on SPI also suggested that the drought severity is very critical in the mountainous areas, which in general, are more vulnerable to drought phenomenon rather than other parts of the country

Calculating Data Driven Drought Indices for the Struma River Basin provides the foundation to evaluate hydrometeorological drought and to serve as preliminary assessment of the risk of drought events in other drought exposed basins. 


\section{References}

1. Andreu, J., Solera, A., Paredes-Arquiola, J., Haro-Monteagudo, D. , van Lanen, H. A. J., Eds.: Drought: Research and Science-Policy Interfacing. Taylor \& Francis Group, London. European Commission. Drought Management Plan Report Including Agricultural, Drought Indicators and Climate Change Aspects (Water Scarcity and Droughts Expert Network), Technical report 2008-023 (2015).

2. Vasiliades L, Loukas A, Liberis N.: A water balance derived drought index for Pinios River Basin, Greece. Water Resour Manage 25:1087-1101 (2011).

3. Tallaksen, L.M.; Hisdal, H.; Lanen, H.A.J.V.: Space-time modelling of catchment scale drought characteristics. J. Hydrol., 375, 363-372 (2009).

4. Mishra A. K., Singh V. P.: Drought modeling - a review. Journal of Hydrology.;403(12):157-175. doi: 10.1016/j.jhydrol.2011.03.049. [Cross Ref] (2011).

5. Van Loon, A.F. :Hydrological drought explained. Wiley Interdiscip. Rev. Water 2, 359392.AF (2015).

6. Dai A, Trenberth KE, Qian T.: A global dataset of Palmer Drought Severity Index for 18702002: relationship with soil moisture and effects of surface warming. J. Hydrometeorol. 5(6): 1117-1130 (2004).

7. Sheffield, J., Wood, E.F., Roderick, M.L.: Little change in global drought over the past 60 years. Nature 491, 435-438 (2012).

8. Stahl K, Kohn I, Blauhut V, Urquijo J, De Stefano L, Acacio V, DiasS, Stagge JH, Tallaksen LM, Kampragou E, Van Loon AF, Barker LJ, Melsen LA, Bifulco C, Musolino D, de Carli A, Massarutto A, Assimacopoulos D, Van Lanen HAJ.: Impacts of European drought events: insights from an international database of text-based reports. Natural Hazards Earth System Sciences 16: 801-819. DOI:10.5194/nhess-16-801-2016 (2016).

9. Water Scarcity \& Droughts in the EU. Brussels, April 272010.

10. Poljanšek, Marin Ferrer, K. M., De Groeve, T., Clark, I.: Science for disaster risk management: knowing better and losing less. Luxembourg: Publications Office of the European Union (https://ec.europa.eu/jrc/en/publication/ science-disaster-risk-management-2017knowing-better-and-losing-less) (2017).

11. MOEW. National strategy for management and development of the water sector in Bulgaria. Sofia (2012).

12. Koleva, E., Alexandrov, V.: Drought in the Bulgarian low regions during the 20th century Theoretical and Applied Climatology (2008).

13. Heim, R. R. Jr.: A review of twentieth-century drought indices used in the United States. Bull. Amer. Meteor. Soc., 83, 1149-1165 (2002).

14. McKee, T. B., Doesken, N. J., Kleist, J.: The relationship of drought frequency and duration to time scales. Preprints, Eighth Conf. on Applied Climatology, Anaheim, CA, Amer. Meteor. Soc., 179-184 (1993).

15. Vicente-Serrano, S. M., Begueria, S., Lopez-Moreno, J. I: A multi-scalar drought index sensitive to global warming: the Standardized Precipitation Evapotranspiration Index. Journal of Climate, 23, 1696-1718 (2010).

16. Begueria, S., Vicente-Serrano, S.M., Angulo-Martinez, M.: A multiscalar global drought dataset: The SPEI base. Bulletin of the American Meteorological Society, 91, 1351-1354 (2010).

17. Vicente-Serrano, S. M, Beguería, S., López-Moreno.: Comment on "Characteristics and trends in various forms of the Palmer Drought Severity Index (PDSI) during 1900-2008” by A. Dai. Journal of Geophysical Research-Atmosphere 116(19), D19112, (2011). 
1. McKee T.B., Doesken N.J., Kleist J. Drought monitoring with multiple time scales, Preprints of the 9th Conference of Applied Climatology, 15-20, Dallas, Texas, 233-236 (1995).

2. Vermes L. How to work out a drought mitigation strategy. An ICID Guide, DVWK Guidelines for water management, 309, 29 pp. (1998).

3. World Meteorological Organization. Standardized Precipitation Index User Guid. 2012.

4. Khadr, M., Morgenschweis, G. and Schlenkhof, A. Analysis of Meteorological Drought in the Ruhr Basin by Using the Standardized Precipitation Index. International Conference on Sustainable Water Resources Management (SWRM2009),Amsterdam - Netherland (2009).

5. Karavitis, C. A., Alexandris, S., Tsesmelis, D. E. \& Athanasopoulos, G. Application of the Standardized Precipitation Index (SPI) in Greece. Water 3(3), 787-805 (2011b).

6. Costa, A. C. Local patterns and trends of the Standard Precipitation Index in southern Portugal (1940-1999), Adv. Geosci., 30, 11- 16, doi:10.5194/adgeo-30-11-2011, (2011).

7. Łabędzki L. Estimation of local drought frequency in central Poland using the standardized precipitation index SPI, Irrigation and Drainage, 56 (1), 67-77, DOI: 10.1002/ird.285 (2007).

8. Gocheva, A., Malcheva K., Marinova T. Some drought indices on the territory of Bulgaria. BJNH, vol 15/4, 88-96 (2010).

9. Alexandrov, V., Radeva S., Koleva E. Utilization of SPI, PDSI, and RDI as drought indicators in South Bulgaria. 11th International Multidisciplinary Geoconference Proceedings Volume II, p. 969-976 (2011).

10. Nikolova, N. Linkages between NAO and River Runoff in Struma River Catchments (Bulgaria). Meteorologický časopis, 15, 2012, 59 - 65 (2012).

11. Nalbantis, I., Tsakiris, G. Assessment of hydrological drought revisited. Water Resources Manag. 23, 881-897 (2009).

12. Rimkus, E., et al. Dynamics of meteorological and hydrological droughts in the Neman river basin, Environ. Res. Lett., 8, 045014 (2013).

13. Liu L, Hong Y, Bednarczyk CN, Yong B, Shafer MA, Riley R, Hocker JE. Hydro climatologicaldrought analyses and projections using meteorological and hydrological drought indices: a case study in Blue River Basin, Oklahoma. Water Resour Manage 26:2761-2779 (2012).

14. Tabari, H., Nikbakht, J., Talaee, P.H. Hydrological Drought Assessment in Northwestern Iran Based on Streamflow Drought Index (SDI). Water Resources Manag. 27, 137-151 (2013).

15. Hong, X., Shenglian, G., Yanlai, Z., Xiong L. Uncertainties in assessing hydrological drought using streamflow drought index for the upper Yangtze River basin. Stochastic Environmental Research and Risk Assessment 29(4) (2015).

16. Gumus V, Algin H M (2016) Meteorological and hydrological drought analysis of the Seyhan- Ceyhan River basins, Turkey. Meteorol Appl 24(1):62-73 (2016).

17. Madadgar, S., Moradkhani, H. Drought Analysis under Climate Change Using Copula. J. Hydrol. Eng. 2013, 18, 746-759 (2013).

18. River basin management plan (Struma River), 2010-2015 (PURB), West Aegean Sea River Basin Directorate -Blagoevgrad.

19. Keyantash J, Dracup J. A. The Quantification of Drought: An Evaluation of Drought Indices. Bulletin American Meteorological Society, August 2002, p. 1167-1180 (2002).

20. Edwards, D. C., and T. B. McKee. Characteristics of 20th century drought in the United States at multiple time scales. Climatology Report No. 97-2, Colorado State Univ., Ft. Collins, CO (1997).

21. Olukayode Oladipo, E. A comparative performance analysis of three meteorological drought indices, J. Climatol., 5(6), 655-664, doi:10.1002/joc.3370050607 (1985). 
22. Nikolova, N., Vassilev S. Variability of Summer-Time Precipitation in Danube Plain, Bulgaria.. Collection of Papers, N 54, Geographic Institute "Jovan Cvijc”Serbian Academy of Sciences and Arts, Belgrade, pp. 19 -32 (2005).

23. Hänsel S, Matschullat J. Drought in a Changing Climate, Saxon Dry Periods. Bioclimatological Conference 2006. Bioclimatology and water in the land. International scientific conference, 11 - 14 September 2006, Strecno, Slovakia (2006).

24. Hänsel, S., Schucknecht, A. Matschullat, J. The Modified Rainfall Anomaly Index (mRAI) - is this an alternative to the Standardised Precipitation Index (SPI) in evaluating future extreme precipitation characteristics?. Theoretical and Applied Climatology. Volume 123, Issue 3-4, pp 827-844 (2016).

25. Fluixá-Sanmartín J., D. Pan, L, Fischer, B, Orlowsky, J. García-Hernández, F. Jordan, Ch. Haemmig, F. Zhang, J.Xu. Searching for the optimal drought index and time scale combination to detect drought: a case study from the lower Jinsha River Basin, China. Hydrol. Earth Syst. Sci., 22, 889-910 (2018). 